ARTIGO DE OPINIÃO OPINION ARTICLE

\title{
Silicone tape versus micropore tape to prevent medical adhesive-related skin injuries: systematic review and meta-analysis
}

\author{
Fita de silicone versus fita microporosa para \\ prevenção de lesão cutânea relacionada a adesivos \\ médicos: revisão sistemática e metanálise
}

André Soares Santos ${ }^{1,2}$, Aline Cunha Terra1,3, José Luiz dos Santos Nogueira1, Kenya Valéria Micaela de Souza Noronha², Juliana de Oliveira Marcatto ${ }^{4}$, Mônica Viegas Andrade²

DOI: 10.21115/JBES.v11.n3.p271-82

\section{Keywords:}

surgical tape, skin, wounds and injuries, biomedical technology assessment, review

\section{Palavras-chave:}

fita cirúrgica, pele, ferimentos e lesões, avaliação da tecnologia biomédica, revisão

\begin{abstract}
Objective: This study aims to compare the efficacy and safety of silicone tapes compared to microporous tapes in patients with fragile skin. Methods: A systematic review of the scientific literature was carried out. Clinical trials that compared silicone tape for medical use with the microporous tape in preterm newborns, newborns, children, elders, or people with increased risk of MARSI were included. This report followed the principles of the PRISMA statement. Results: Three randomized controlled trials were included. The silicone tape was associated with fewer injuries $(R R=0.53 ; p$-value $=0.03)$, but no difference was found in terms of prevention of moderate or severe injuries ( $R R=0.25 ; p$-value $=0.20$ ). Silicone tapes produce significantly less edema/erythema response than microporous tapes in children $(M D=-0.42 ; \mathrm{p}$-value $<0.0001)$. The quality of evidence was considered very low. Conclusion: The evidence suggests that silicone tapes may be gentler to patients'skin than microporous tapes. However, no study reported data on the outcomes of interest. The studies have small samples, a short time horizon, and the quality of evidence was considered very low. There is insufficient information to allow the recommendation of silicone tapes to prevent skin injuries compared to microporous tapes.
\end{abstract}

\section{RESUMO}

Objetivo: $O$ objetivo deste estudo é avaliar a eficácia e a segurança das fitas de silicone comparadas às fitas microporosas em pacientes com pele frágil. Métodos: Uma revisão sistemática da literatura foi conduzida. Ensaios clínicos que compararam a fita de silicone para uso médico com a fita microporosa em pacientes prematuros, neonatos, crianças, idosos ou pessoas com risco aumentado de lesão por adesivos médicos foram incluídos. Esse relato seguiu os princípios do relatório PRISMA. Resultados: Três ensaios clínicos randomizados foram incluídos. As fitas de silicone foram associadas a menor risco de lesões ( $R R=0,53$; valor- $p=0,03$ ), mas não foi observada diferença em termos de lesões moderadas ou graves ( $R R=0,25$; valor- $p=0,20$ ), e produziram significativamente

Received on: 03/15/2019. Approved for publication on: 09/29/2019.

1. Núcleo de Avaliação de Tecnologias em Saúde (NATS-HC/UFMG) - Universidade Federal de Minas Gerais, Belo Horizonte, MG, Brazil. 2. Department of Economical Sciences - School of Economical Sciences - Universidade Federal de Minas Gerais, Belo Horizonte, MG, Brazil.

3. Department of Applied Nursing - Nursing School - Universidade Federal de Minas Gerais, Belo Horizonte, MG, Brazil. 4. Department of Maternal Child Nursing - Universidade Federal de Minas Gerais, Belo Horizonte, MG, Brazil.

Information on aid received in the form of financing, equipment or medicines: This study was funded by the Brazilian research promoting organizations Conselho Nacional de Desenvolvimento Científico e Tecnológico (CNPq), Instituto de Avaliação de Tecnologias em Saúde (IATS) and Fundação de Amparo à Pesquisa do Estado de Minas Gerais (Fapemig). No pharmaceutical industries contributed with resources for this study.

Congress: This study was not yet presented in any event. It was, though, submitted to the ISPOR Latin America 2019 that happened between September $12^{\text {th }}$ and $14^{\text {th }}$ in Bogota, Colombia. It is original and was not submitted to any other journal. All the authors collaborated with the final manuscript.

Conflict of interests: The authors declare to have no conflicts of interest that could influence the results.

Corresponding author: André Soares Santos. Departamento de Ciências Econômicas, Faculdade de Ciências Econômicas, sala 2064, Universidade Federal de Minas Gerais. Av. Presidente Antônio Carlos, 6627 - Pampulha, Belo Horizonte, MG, Brazil. CEP 31270-901. Telephone: +55 (31) 99180-8788. E-mail: andresantos111@ufmg.br 
menos edema/eritema que fitas microporosas em crianças ( $M D=-0,42$; valor- $p<0,0001$ ). A qualidade da evidência foi considerada baixa. Conclusão: A evidência sugere que as fitas de silicone são mais gentis à pele dos pacientes que as fitas microporosas. No entanto, nenhum estudo incluído reportou dados sobre os desfechos de interesse. Os estudos tinham amostras pequenas, horizonte temporal curto e qualidade de evidência muito baixa. A informação existente é insuficiente para possibilitar a recomendação das fitas de silicone para prevenção de lesões cutâneas em comparação com as fitas microporosas.

\section{Introduction}

Medical adhesives are used to affix external components to patient skin in procedures of all medical specialties. They comprise a variety of products, such as tapes, dressings, electrodes, and others (McNichol et al., 2013; Farris et al., 2015; Ratliff, 2017). Medical tapes are a base that acts as a carrier for an adhesive. The type of base and adhesive incorporated into the tape determine its properties and performance. Some types of adhesive are acrylates, silicones, hydrogels, hydrocolloids, latex, and polyurethanes. A firm pressure applied to the surface activates the adhesive by increasing its contact area with the skin (Cutting, 2008; McNichol et al., 2013; Ratliff, 2017). The nature of the support, whether paper, plastic, silk, cloth, elastic, or foam, is associated with the stretching, conformability, and stiffness of the adhesive (Ratliff, 2017). The objective of medical tapes is to provide safe affixation for critical and non-critical devices and products as well as to facilitate the protection and healing of the skin. However, cutaneous trauma related to its repetitive application and removal is prevalent and underestimated. These injuries are associated with pain, risk of infections, delayed healing, decreased quality of life, and increased treatment costs (Cutting, 2008; Konya et al., 2010; Maene, 2013; McNichol et al., 2013; Zeng et al., 2016).

A Medical Adhesive-Related Skin Injury (MARSI) is a manifestation of cutaneous abnormality that persists for more than 30 minutes after the removal of an adhesive (McNichol et al., 2013; Farris et al., 2015; Zhao et al., 2018a). Repeated or improper applications and removals, as well as the selection of an inappropriate type of tape for a particular location without considering the purpose or the patient's skin type, can cause skin injuries associated with tapes (Maene, 2013). Some of the most common types of adhesive-related injuries are: i. skin stripping, which occurs when the epidermis is removed by the repeated application and removal of the tape, denuding and wounding the skin (Cutting, 2008; Maene, 2013; Ratliff, 2017; Zhao et al., 2018a); ii. skin tears, which can occur by applying and removing the tapes or by its friction in patients with fragile skin (e.g., older people and newborns), causing skin layers to separate (Maene, 2013; Ratliff, 2017; Zhao et al., 2018a); iii. tension blisters, which occur when the tape stretches the skin and, to restore its former shape, it pulls epidermal layers (Maene, 2013; Ratliff, 2017; Zhao et al., 2018a); and iv. dermatitis, which occurs when irritants get stuck between the skin and the adhesive (Maene, 2013; Zhao, et al., 2018a).

Several authors have studied the prevalence and incidence of MARSIs over the years. Ratliff (2017), in a study with patients aged 52-83 years, reported that 5.8\% of them (7/120) arrived at the clinic with medical-adhesive related wounds. In six of seven patients, the wound was associated with the removal of paper tapes, either by a health professional $(N=4)$ or by the patient himself $(N=2)$ (Ratliff, 2017). Farris et al. (2015) observed an average daily prevalence of MARSIs of 13\% in two care units of a US teaching hospital. This average was higher in the group of individuals between 65 and 74 years-old (20.9\%). Regarding severity, $85.5 \%$ of the injuries were considered mild, 13.6\% moderate, and 0.8\% severe (Farris et al., 2015). Zhao et al. (2018a) observed a prevalence of $19.7 \%$ of MARSI in four tertiary hospitals in China. Mechanical lesions (5.0\%, 35/697), contact dermatitis (14.8\%, 103/697), folliculitis (1.0\%, 7/697) and damage associated with moisture $(1.3 \%, 9 / 697)$ were reported. Among the mechanical injuries, skin tears $(0.9 \%, \mathrm{~N}=6)$, skinstripping $(1.3 \%, N=9)$, and tension blisters $(2.4 \%, N=17)$ were the most common (Zhao et al., 2018b).

Fragile skins are particularly susceptible to MARSI. Although there is no formal definition for fragile or at-risk skin, they are usually characterized by thin skins that tear easily. Genetic predisposition, aging, ethnicity, dermatological conditions, other medical conditions (e.g., diabetes, infections, renal failure, heart failure), malnutrition, dehydration, some drugs (e.g., corticosteroids, chemotherapeutics, immunosuppressants and anticoagulants), and sun exposure are associated to this susceptibility (Cutting, 2008; Denyer, 2011; Grove et al., 2013; McNichol et al., 2013; Manriquez et al., 2014; Ratliff, 2017). Older adults' skin is thinner, contains less fat, is less resistant to shear forces, has decreased blood circulation, and exhibits weakened dermal-epidermal junctions, making it more fragile and susceptible to trauma than the skin of a healthy adult. Newborn skin is $40 \%$ to $60 \%$ thinner than an adult skin, primarily due to the presence of fewer layers of epidermal cells in the stratum corneum and to the cohesion between dermis and epidermis, creating a less efficient protection (Noonan et al., 2006; Grove et al., 2013, 2014; Maene, 2013; McNichol et al., 2013; Ratliff, 2017). The dermis of a premature newborn is deficient in structural proteins, lacks the coverage of the vertex and tears easily. The poor stratum corneum integrity increases the risk of water loss, thermal instability, and infections (Eichenfield \& Hardaway, 
1999). Konya et al. (2010) reported an incidence of $15.5 \%$ of tape injuries in patients older than 65 years old. Noonan et al. (2006) observed that 8\% (20/253) of the children and infants admitted to a tertiary teaching hospital presented skin-stripping by application and removal of adhesive tapes. Many of these injuries were considered preventable (Noonan et al., 2006; Chang et al., 2016).

Based on that, professionals of a teaching hospital in Brazil requested the incorporation of a silicone adhesive tape for patients with fragile skin. Currently, the hospital uses microporous tapes for the fixation of sensors, probes, and dressings. According to the applicant, the use of this tape causes an increase in the superficial tension of the skin with time and during the removal it favors the occurrence of MARSIs, characterized by skin abrasion, erythema, and even ulcerations. From the request for the incorporation of silicone tapes, arguing that these are safer for patients and may also be cost-effective, a systematic review was conducted to compare silicone tapes with microporous tapes for patients with fragile skin or at increased risk of developing MARSIs. This assessment is in the interest of various institutions that currently face this decision. To our knowledge, there are no published systematic reviews that address this problem.

\section{Methods}

A systematic review of the scientific literature was carried out to evaluate the efficacy, safety, and effectiveness of the silicone tapes in comparison to microporous tapes in patients with fragile skin. We included studies conducted with premature patients, neonates, infants, children, elders, or patients with high susceptibility to MARSI. This report followed the principles of the PRISMA statement (Moher et al., 2009).

\section{Research question}

Does silicone tape provide a lower risk of skin injuries or infections and a shorter length of stay than microporous tape when used to affix medical products to patients with fragile skin? The research question posed in PICO format is available in Supplementary Materials - Appendix A.

\section{Search strategy}

A systematic search of the scientific literature was conducted in Medline (via PubMed), The Cochrane Library, and Lilacs for epidemiological studies reporting head-to-head comparisons between the silicone adhesive tape and the microporous (acrylate) adhesive tape in patients at risk of developing MARSI. An additional search was performed on the references of included studies and Google Scholar. Searches were conducted on August $9^{\text {th }}, 2018$, and repeated on February $5^{\text {th }}, 2019$. References were imported to EndNote ${ }^{\oplus}$ 7.5 to remove the duplicates and then transported to Microsoft Excel ${ }^{\otimes} 2013$ for the selection process. Contacts were made with the companies $3 \mathrm{M}$ and Parafix, to obtain more information and references that had not been identified. $3 \mathrm{M}$ submitted four articles, three of which had already been identified. The other was a survey, which was included in the selection process. The company Parafix forwarded a booklet. Search strategies and results by database are available in

\section{Supplementary Materials - Appendix B}

\section{Selection criteria}

Clinical trials that compared silicone tape with microporous tape for medical use in preterm newborns, newborns, children, elders, or people with increased risk of MARSI were included. The status of the elderly in Brazil includes people aged 60 years old or more (Brasil, 2003); therefore, this review included studies that reported the median age of participants older than 60 years. There was no restriction for date, language, or location restrictions. In phase 1, the references were selected based on the title and abstract by two independent researchers (AS and TA) and divergences were resolved by consensus. In phase 2, the full texts were assessed. Again, divergences were decided by consensus. In phase 3, data were collected regarding the outcomes indicated in the research question by one researcher (AT) and checked by another (AS). A list of articles excluded in phase 2 with motives is available in Supplementary Materials Appendix C.

\section{Data analysis}

A qualitative synthesis was initially presented with the results from the included trials. The quantitative synthesis was constructed in Review Manager ${ }^{\circledR}$ 5.3. Since the study populations were considered too different to aggregate in a meta-analysis, the software was used as a convenient way to calculate and present data extracted from the original articles.

Appendix A. Research question posed in PICO format

\begin{tabular}{ll}
\hline P- Population & Patients with fragile skin \\
\hline I- Intervention & Silicone tape \\
\hline C - Comparator & Microporous tape \\
\hline O - Outcomes & $\begin{array}{l}\text { Medical Adhesive-Related Injuries, length of inpatient stay, } \\
\text { incidence of infections }\end{array}$ \\
\hline S - Setting & Hospital \\
\hline
\end{tabular}


Appendix B. Search strategies

\section{Children, neonates, preterm}

\begin{tabular}{|c|c|c|c|}
\hline Database & \multicolumn{2}{|c|}{ Strategy } & $N$ \\
\hline PubMed & \multicolumn{3}{|c|}{ 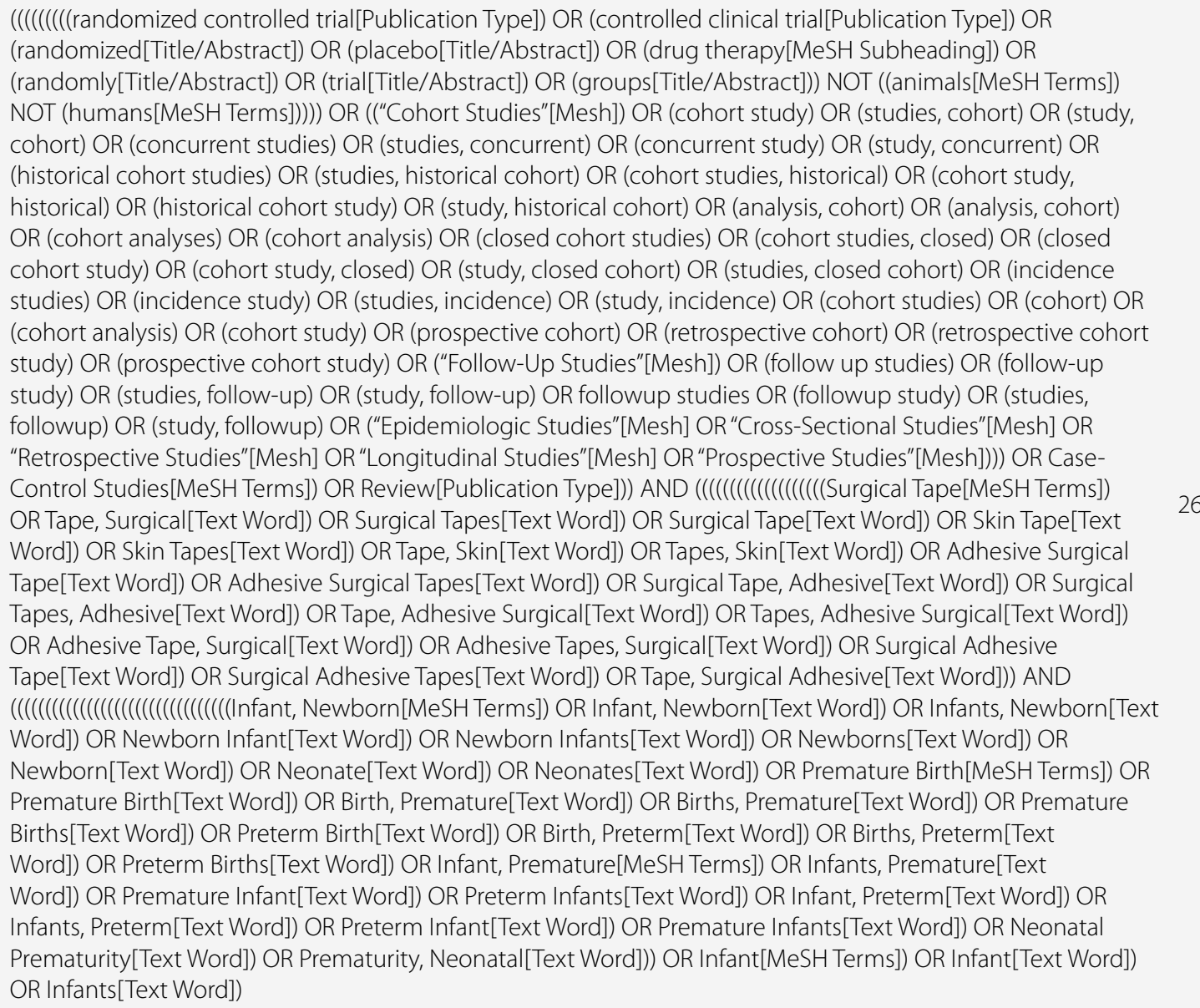 } \\
\hline $\begin{array}{l}\text { The Cochrane } \\
\text { Library }\end{array}$ & $\begin{array}{l}\text { ID } \\
\# 3 \\
\# 4 \\
\# 5 \\
\# 6 \\
\# 7 \\
\# 8 \\
\# 9 \\
\# 10 \\
\# 13 \\
\# 15 \\
\# 16 \\
\# 17 \\
\# 19\end{array}$ & $\begin{array}{l}\text { Search } \\
\text { Surgical Tap } \\
\text { Adhesive Surgical Tapes } \\
\text { Tape } \\
\text { Infant, Newborn } \\
\text { Newborn } \\
\text { Infant } \\
\text { Premature Birth } \\
\text { premature } \\
\text { \#3 or \#4 or \#5 } \\
\text { \#6 or \#7 or \#8 or \#9 or \#10 } \\
\text { \#15 and \#13 } \\
\text { silicone } \\
\# 16 \text { and \#18 }\end{array}$ & 9 \\
\hline
\end{tabular}

(tw:((tw:(Infant, Newborn)) OR (tw:(Recém-Nascido)) OR (tw:(Recién Nacido)) OR (tw:(Newborn)) OR 


\begin{tabular}{|c|c|c|c|}
\hline \multicolumn{4}{|l|}{ Elder } \\
\hline Database & \multicolumn{2}{|c|}{ Strategy } & $\mathbf{N}$ \\
\hline PubMed & \multicolumn{2}{|r|}{ 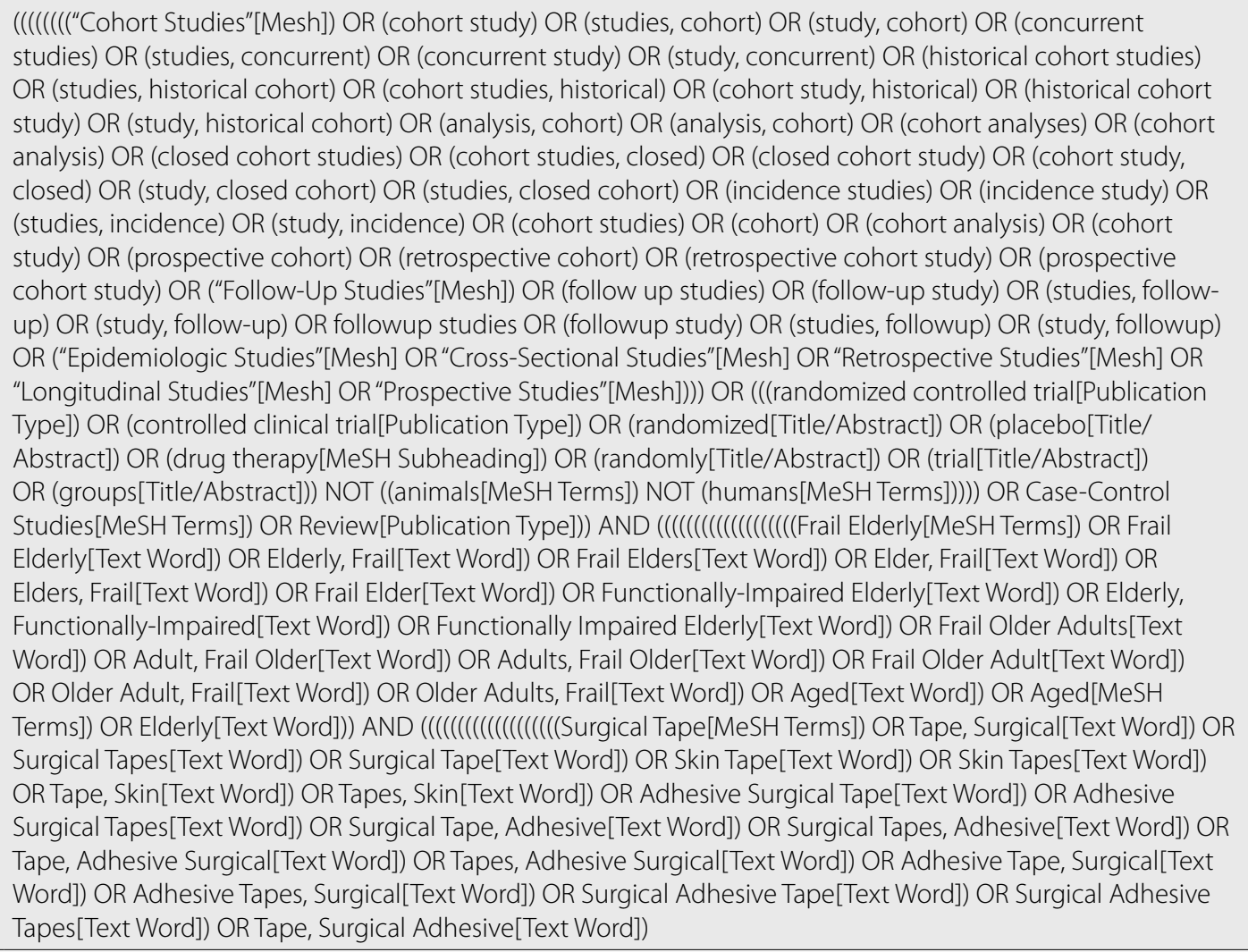 } & 149 \\
\hline $\begin{array}{l}\text { The Cochrane } \\
\text { Library }\end{array}$ & $\begin{array}{l}\text { ID } \\
\# 1 \\
\# 2 \\
\# 3 \\
\# 4 \\
\# 5 \\
\# 11 \\
\# 12 \\
\# 13 \\
\# 14 \\
\# 17 \\
\# 18 \\
\end{array}$ & $\begin{array}{l}\text { Search } \\
\text { Frail Elderly } \\
\text { Aged } \\
\text { Surgical Tap } \\
\text { Adhesive Surgical Tapes } \\
\text { Tape } \\
\text { elder } \\
\# 1 \text { or \#2 or \#11 } \\
\# 3 \text { or \#4 or \#5 } \\
\# 12 \text { and \#13 } \\
\text { silicone } \\
\# 14 \text { and \#17 }\end{array}$ & 36 \\
\hline Lilacs & $\begin{array}{l}\text { (tw: } \\
\text { OR } \\
\text { Cirúr }\end{array}$ & $\begin{array}{l}\text { Aged)) OR (tw:(Anciano)) OR (tw:(Idoso)) OR (tw:(Idosa)) OR (tw:(Frail Elderly )) OR (tw:(Anciano Frágil)) } \\
\text { doso Fragilizado)) OR (tw:(Elder)))) AND (tw:((tw:(Surgical Tape)) OR (tw:(Cinta Quirúrgica )) OR (tw:(Fita } \\
\text { )) OR (tw:(Micropore)) OR (tw:(microporosa)) OR (tw:(Tape)))) }\end{array}$ & 153 \\
\hline \multicolumn{4}{|c|}{ Medical Adhesive-Related Skin Injury } \\
\hline PubMed & $\begin{array}{l}(((((A) \\
((((() \\
\text { Deg } \\
\text { Wor } \\
\text { Deg } \\
\text { Avul } \\
\text { Skin }\end{array}$ & $\begin{array}{l}\text { sives) OR Adhesives[Text Word]) OR Adhesive[Text Word]) OR Tissue Adhesives[MeSH Terms])) AND } \\
\text { ((((((Degloving Injuries) OR Degloving Injuries[Text Word]) OR Degloving Injury[Text Word]) OR Injuries, } \\
\text { g[Text Word]) OR Injury, Degloving[Text Word]) OR Skin Avulsion[Text Word]) OR Avulsion, Skin[Text } \\
\text { R Avulsions, Skin[Text Word]) OR Skin Avulsions[Text Word]) OR Degloving Wounds[Text Word]) OR } \\
\text { ig Wound[Text Word]) OR Skin Avulsion Injuries[Text Word]) OR Avulsion Injuries, Skin[Text Word]) OR } \\
\text { Injury, Skin[Text Word]) OR Injuries, Skin Avulsion[Text Word]) OR Injury, Skin Avulsion[Text Word]) OR } \\
\text { Ision Injury[Text Word])) OR medical adhesive-related skin injury) }\end{array}$ & 23 \\
\hline
\end{tabular}




\begin{tabular}{|c|c|c|c|}
\hline $\begin{array}{l}\text { The Cochrane } \\
\text { Library }\end{array}$ & $\begin{array}{l}\text { ID } \\
\# 1 \\
\# 2 \\
\# 3 \\
\# 4 \\
\# 5 \\
\# 6 \\
\# 7 \\
\# 8 \\
\# 9 \\
\# 10\end{array}$ & $\begin{array}{l}\text { Search } \\
\text { Adhesives } \\
\text { Tissue Adhesives } \\
\text { Adhesive\$ } \\
\text { \#1 or \#2 or \#3 } \\
\text { medical adhesive-related skin injury } \\
\text { Degloving Injuries } \\
\text { Skin Avulsion } \\
\text { Skin Avulsion Injuries } \\
\text { \#6 OR \#7 OR \#8 OR \#5 } \\
\text { \#4 and \#9 }\end{array}$ & 6 \\
\hline Lilacs & \multicolumn{2}{|r|}{$\begin{array}{l}\text { (tw:(adhesive*)) AND (tw:((tw:(medical adhesive-related skin injury)) OR (tw:((tw:(Degloving Injur*)) OR } \\
\text { (tw:(Skin Avulsion Injury)) OR (tw:(Skin Avulsion*))))) }\end{array}$} & 1 \\
\hline \multicolumn{3}{|c|}{ Contributions from the producer companies } & 4 \\
\hline \multicolumn{3}{|l|}{ Snowballing } & 2 \\
\hline \multicolumn{3}{|l|}{ Total } & 428 \\
\hline \multicolumn{3}{|c|}{ Total after duplicate removal } & 411 \\
\hline \multicolumn{3}{|c|}{ References in the second phase } & 13 \\
\hline \multicolumn{3}{|c|}{ Included references } & 3 \\
\hline
\end{tabular}

Appendix C. List of excluded studies in the second phase of the selection process

\begin{tabular}{|c|c|}
\hline Study & Motive \\
\hline $\begin{array}{l}\text { Anderson A, Foster RS, Brand R, Blyth CC, Kotecha RS. Acute Onset of Pustules at the Site of Tape } \\
\text { Placement in an Immunocompromised Infant with Acute Myeloid Leukemia. Pediatr Dermatol. } \\
\text { 2014;31:609-610. }\end{array}$ & Study Design \\
\hline $\begin{array}{l}\text { Cutting KF. Impact of adhesive surgical tape and wound dressings on the skin, with reference to } \\
\text { skin stripping. J Wound Care 2008; 17: 157-62. }\end{array}$ & Study Design \\
\hline $\begin{array}{l}\text { Denyer J: Reducing pain during the removal of adhesive and adherent } \\
\text { products.Br J Nurs. 2011, 20:S28. S30-S35. }\end{array}$ & Study Design \\
\hline $\begin{array}{l}\text { Farris MK, Petty M, Hamilton J , Walters SA, Flynn MA. Medical adhesive related skin injury among } \\
\text { adult acute care patients: a single-center observational study . J Wound Ostomy Continence Nurs. } \\
\text { 2015;42(6):589-598. }\end{array}$ & Intervention \\
\hline Maene, B. Hidden costs of medical tape-induced skin injuries. Wounds UK, v. 9, n. 1, p. 46-50, 2013. & Study Design \\
\hline $\begin{array}{l}\text { Manriquez B.; Smith, G., S. . L. et al. Evaluation of a new silicone adhesive tape among clinicians caring for } \\
\text { patients with fragile or at-risk skin. Adv Skin Wound Care, v. 27, n. 4, p. 163-170, abr. } 2014 .\end{array}$ & Study Design \\
\hline $\begin{array}{l}\text { Ratliff, C. R. Descriptive study of the frequency of medical adhesive-related skin injuries in a vascular } \\
\text { clinic. J Vasc Nurs, v. 35, n. 2, p. 86-89, } 2017 .\end{array}$ & Intervention \\
\hline $\begin{array}{l}\text { Zhao, H. et al. Medical Adhesive-Related Skin Injury Prevalence at the Peripherally Inserted Central } \\
\text { Catheter Insertion Site. Journal of Wound, Ostomy and Continence Nursing, v. 45, n. 1, p. 22-25, 2018a. }\end{array}$ & Intervention \\
\hline $\begin{array}{l}\text { Zhao, H. et al. Prevalence of medical adhesive-related skin injury at peripherally inserted central catheter } \\
\text { insertion site in oncology patients. The Journal of Vascular Access, v. 19, n. 1, p. 23-27, } 19 \text { jan. } 2018 \mathrm{~b} \text {. }\end{array}$ & Intervention \\
\hline
\end{tabular}

\section{Breternitz M, Flach M, Prässler J, Elsner P, Fluhr JW. Acute barrier disruption by adhesive tapes is Intervention} influenced by pressure, time and anatomical location: integrity and cohesion assessed by sequential tape stripping. A randomized, controlled study. Br J Dermatol. 2007 Feb;156(2):231-40. 


\section{Quality assessment}

To evaluate the methodological quality of the studies, the Cochrane Collaboration Risk of Bias Scale for randomized clinical trials was applied (Higgins \& Green, 2011). The Grading of Recommendations Assessment, Development and Evaluation (GRADE) system was used to evaluate the level of evidence and strength of recommendation. The quality of the evidence was classified into four levels: high, moderate, low, and very low (Guyatt et al., 2008c; Guyatt et al., 2008a; Guyatt et al., 2008b; Guyatt et al., 2008d; Higgins \& Green, 2011; Brasil, 2014; Toma et al., 2017).

\section{Results}

\section{Study selection}

Four hundred eleven references were included in the selection process after duplicate removal. In the first phase, 398 of these were excluded by title and abstract. The concordance rate among the reviewers in the first phase was higher than 0.96 . Of the 13 references evaluated in the second phase, only three randomized controlled trials were included (Figure 1). The study by Grove et al. (2014) evaluated the effect of silicone tapes and microporous tape in infants and children. We included the study by Grove et al. (2013) because it comprised patients older than 55 years, and the median age was 63 years, although they were healthy. Also, we included the study by Zeng et al. (2016) because it comprised patients at risk of developing MARSIs. The median age in this study was 62 and 63.5 years for the populations randomized to the silicone and acrylate tapes, respectively. The general characteristics and main results of the included studies are available in Supplementary Materials - Appendix D.

\section{Qualitative analysis}

The studies showed a statistically significant difference in skin-stripping favoring the silicone tape (Grove et al., 2013, 2014; Zeng et al., 2016). Two of the three studies showed no significant difference between tapes on the formation of erythema and edema (Grove et al., 2013; Zeng et al., 2016). This difference was only observed in infants and children (Grove et al., 2014). The difference in pain and discomfort during tape removal was significant in two studies (Grove et al., 2014; Zeng et al., 2016). One study demonstrated less keratin removal with silicone tape (Grove et al., 2014), and another, by the same author and funder, showed less transdermal water loss with silicone tape (Grove et al., 2013). Only one of the studies showed a significant patient preference for silicone tape (Zeng et al., 2016).

All three studies showed data suggesting a difference in efficacy between the two types of tapes but did not include this data in the analyzes. Two studies reported the loss of tapes (Grove et al., 2013, 2014). In one, four silicone tapes and no microporous tape were lost (Grove et al., 2014). In another, the author suggests that situations where the tape area might get exposed to moisture or secretions are not suitable for the use of silicone tape (Zeng et al., 2016). One study reports that the edge lifts were significantly more common with the silicone tape (Grove et al., 2014). None of the studies reported the relative risk of total injuries, severe or moderate injuries, and infections, and the difference in length of hospital stay between the silicone tape and the microporous tape.

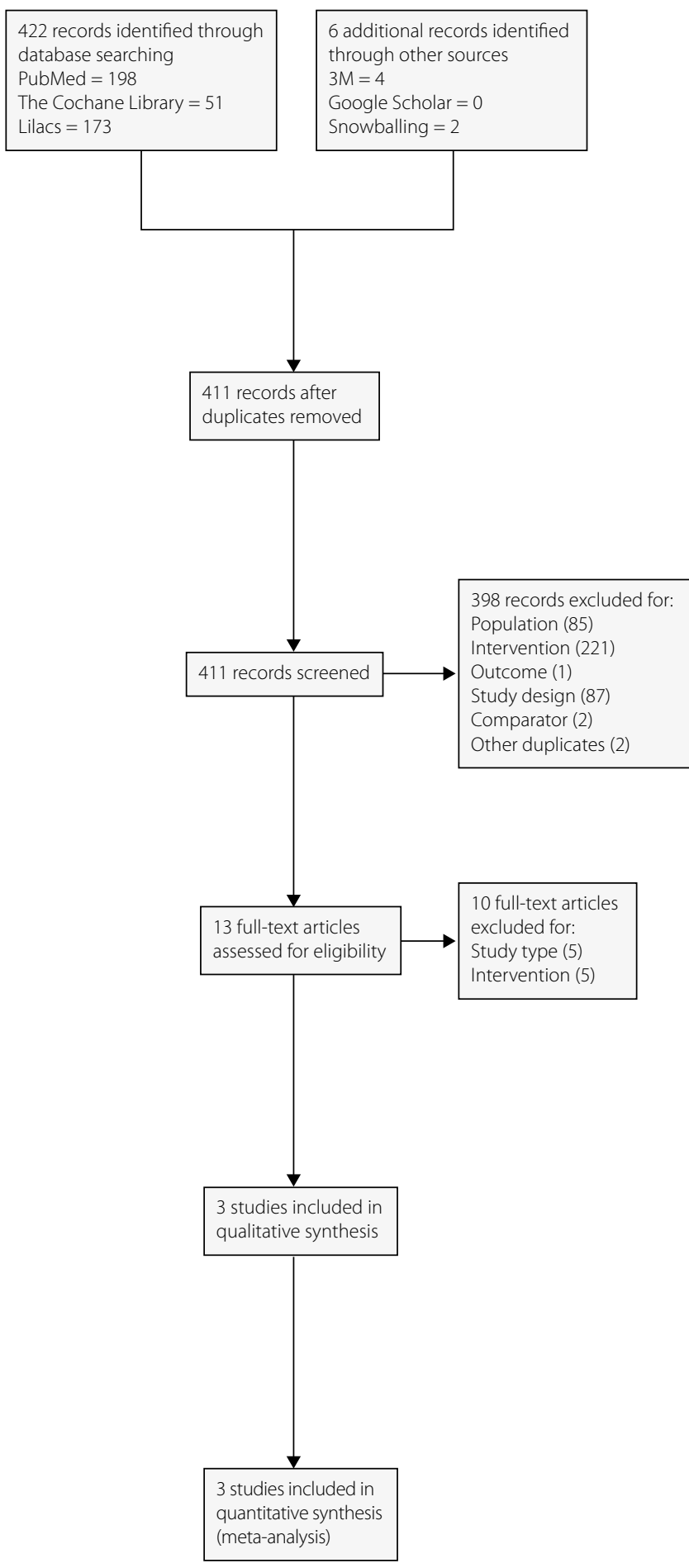

Figure 1. Study flow diagram. 
Appendix D. General Characteristics of included studies

\begin{tabular}{|c|c|}
\hline Study & Grove et al., 2013 \\
\hline General characteristics & $\begin{array}{l}\text { Objectives: To compare gentleness of a silicone tape to a microporous tape. } \\
\text { Methods: Daily placement and removal of tapes, except for weekends, in } 2 \text { of } 3 \text { loci in the forearm. } \\
\text { Population: Healthy volunteers with I, II or III Fitzpatrick skin types. } \\
\mathrm{N}=28 \\
\text { Age: } 55 \text { or older (average: } 63 \text { years-old) } \\
\text { Time horizon: } 11 \text { days } \\
\text { Limitations: Data collected from healthy individuals. }\end{array}$ \\
\hline Safety & $\begin{array}{l}\text { Erythema/Edema } \\
\text { Silicone tape: day } 1-0.60 \text {; day } 4-0.82 \text {; day } 7-0.90 \text {; day } 11-0.94 \text {. P-value }<0.001^{\mathrm{e}} \\
\text { Paper tape: day } 1-0.73 \text {; day } 4-0.80 ; \text { day } 7-0.97 \text {; day } 11-1.16 . \text { P-value }<0.001^{\mathrm{e}} \\
\text { Control: day } 1-0 \text {; day } 4-0.02 \text {; day } 7-0.05 \text {; day } 11-0.13 \\
\text { Skin stripping } \\
\text { Silicone tape: day } 1-0 \text {; day } 4-0.02 \text {; day } 7-0.08 \text {; day } 11-0.13 \\
\text { Microporous tape: day } 1-0.06 \text {; day } 4-0.39 \text {; day } 7-0.51 \text {; day } 11-1 . \\
\text { Control: day } 1-0 \text {; day } 4-0 \text {; day } 7-0 \text {; day } 11-0.01 \text {. }\end{array}$ \\
\hline Study & Grove et al., 2014 \\
\hline General characteristics & $\begin{array}{l}\text { Objectives: To compare gentleness of a silicone tape to a microporous tape in healthy children and babies. } \\
\text { Methods: One placement and removal of tapes } 24 \text {-hours later. } \\
\text { Population: Healthy children with I, II or III Fitzpatrick skin type. } \\
\mathrm{N}=24 \\
\text { Age: } 6 \text { to } 48 \text { months } \\
\text { Sex: } 13 \text { females/11 males } \\
\text { Time horizon: } 24 \text { hours } \\
\text { Limitations: Data from healthy children; single placement and removal of tapes. }\end{array}$ \\
\hline Efficacy & $\begin{array}{l}\text { Loss of tapes } \\
\text { Silicone tape: } 4 \\
\text { Microporous tape: } 0\end{array}$ \\
\hline Safety & $\begin{array}{l}\text { Erythema/Edema } \\
\text { Silicone tape: } 0.93 \pm 0.14 \\
\text { Microporous tape: } 1.35 \pm 0.11 \\
\text { P-value = } 0.0129 \\
\text { Skin stripping } \\
\text { Silicone tape: } 0.00 \\
\text { Microporous tape: } 0.29 \pm 0.11 \\
\text { P-value = } 0.0039 \\
\text { Discomfort } \\
\text { Silicone tape: } 0.5 \\
\text { Microporous tape: } 3.3 \\
\text { P-value }=0.0002 \\
\text { Keratin removal } \\
\text { Silicone tape: } 8.7 \pm 0.5 \\
\text { Microporous tape: } 15.7 \pm 1.3 \\
\text { P-value < } 0.0001\end{array}$ \\
\hline Study & Zeng et al., 2016 \\
\hline General characteristics & $\begin{array}{l}\text { Objectives: To compare the incidence of skin injuries and patient satisfaction of two medical tapes. } \\
\text { Methods: Placement and removal of tapes during surgery. } \\
\text { Population: Patients with elective surgery planned, under general anesthesia, using endotracheal tube. } \\
\mathrm{N}=60 \\
\text { Age: median = } 62 \text { and } 63.5 \text { years-old for silicone and acrylate tapes, respectively. } \\
\text { Interventions: Silicone tape vs. Microporous tape } \\
\text { Time horizon: } 6 \text { months } \\
\text { Limitations: Single placement and removal; lack of standard method to place and remove tapes. }\end{array}$ \\
\hline Efficacy & $\begin{array}{l}\text { Loss of tapes } \\
\text { Silicone tape: } 1 \\
\text { Microporous tape: } 2\end{array}$ \\
\hline
\end{tabular}




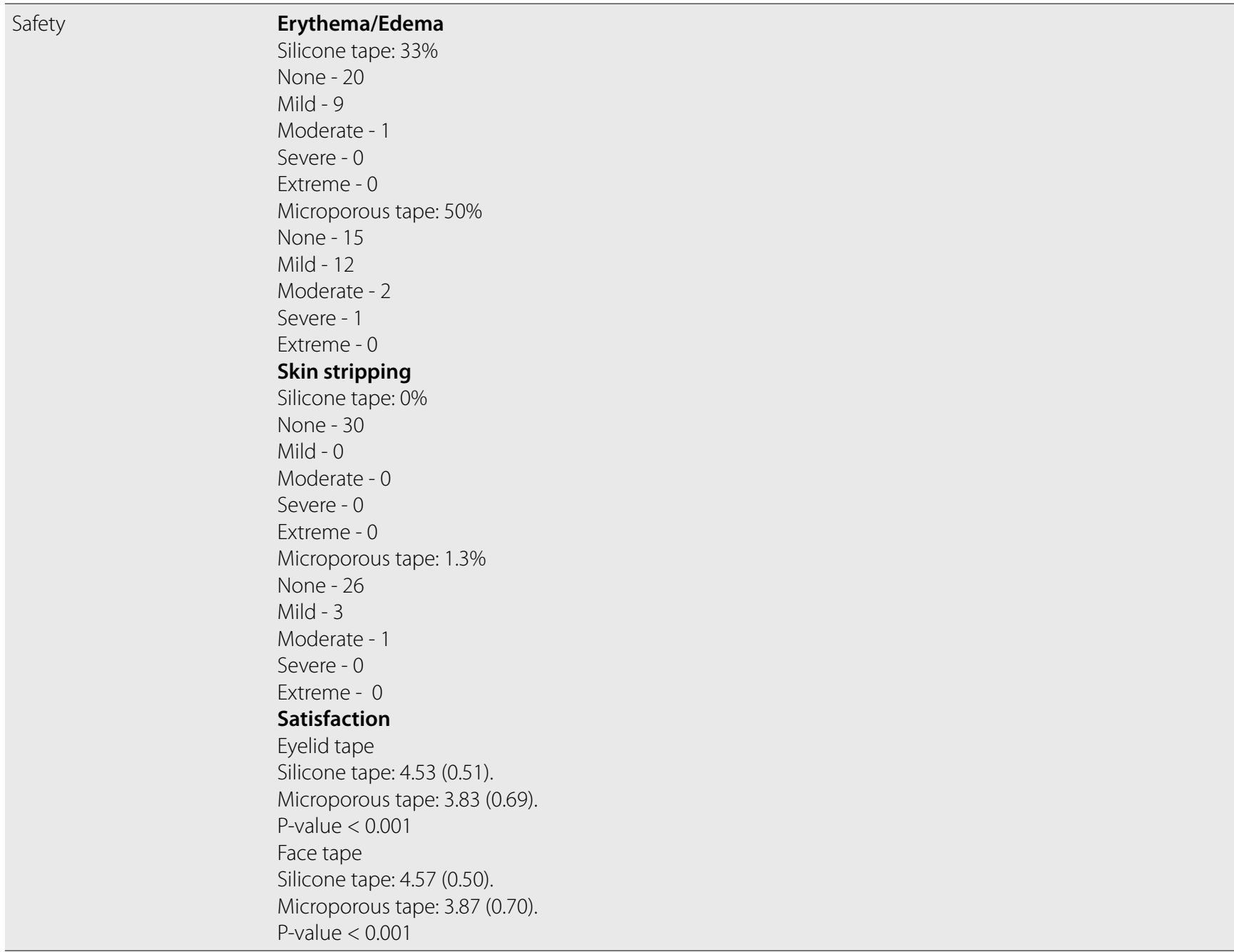

aSignificantly different than control; bSignificantly different than control; ‘Significantly different than silicone tape; ${ }^{d}$ Significantly different than silicone tape; ${ }^{\text {eSignifi- }}$ cantly different than untreated control.

\section{Quantitative analysis}

The data quantitatively assessed suggest that the silicone tapes are associated to less MARSIs (RR $=0.53 ; 95 \% \mathrm{Cl}=$ 0.30 to $0.94 ;$ p-value $=0.03 ; 1$ study; Figure 2). No significant difference was demonstrated in terms of prevention of moderate or severe injuries, probably due to small sample sizes and number of events ( $R R=0.25 ; 95 \% \mathrm{Cl}=0.03$ to 2.11; $p$-value $=0.20 ; 1$ study; Figure 3 ). Silicone tapes produce significantly less edema/erythema response than microporous tapes in children $(\mathrm{MD}=-0.42 ; 95 \% \mathrm{Cl}=-0.60$ to -0.24 ; p-value $<0.0001$; 1 study; Figure 4 ), but not in adults $[\mathrm{MD}=-0.13 ; 95 \% \mathrm{Cl}=-0.94$ to $0.68 ; \mathrm{p}$-value $=0.75$; 1 study (Grove et al., 2013)]. No significant difference in preference for each tape were demonstrated considering children's parents $[\mathrm{RR}=1.30 ; 95 \% \mathrm{Cl}=0.71$ to 2.37 ; $\mathrm{p}$-value $=0.39 ; 1$ study (Grove et al., 2014)] or adult patients [RR = 2.40; $95 \% \mathrm{Cl}=0.90$ to 5.88; $\mathrm{p}$-value $=0.06 ; 1$ study (Grove et al., 2013)]. Patient satisfaction score was higher for the silicone tape than microporous tape, though [EYELIDS: MD $=0.70 ; 95 \% \mathrm{Cl}=0.39$ to $1.01 ; \mathrm{p}$-value $<0.0001 ; 1$ study; FACE: $\mathrm{MD}=0.70 ; 95 \% \mathrm{Cl}=0.39$ to $1.01 ; \mathrm{p}$-value $<0.0001 ; 1$ study (Zeng et al., 2016)].

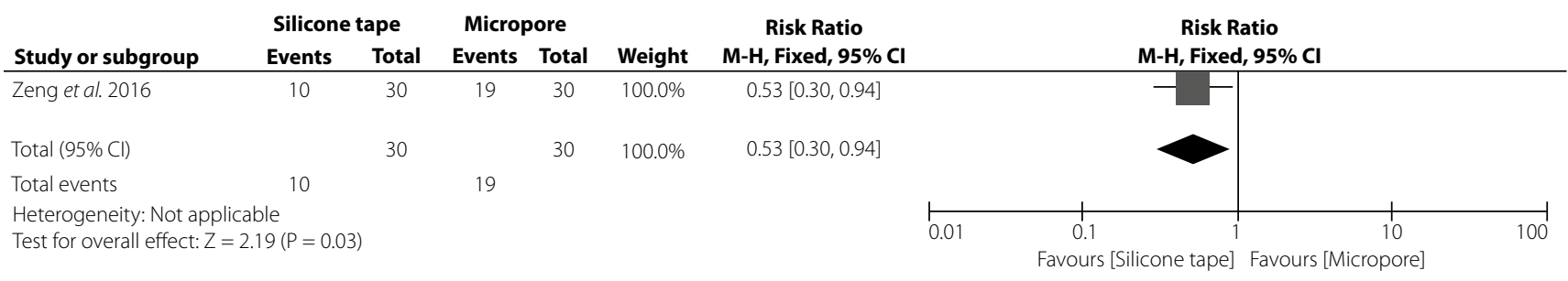

Figure 2. Incidence of injuries on patients with fragile skin. 


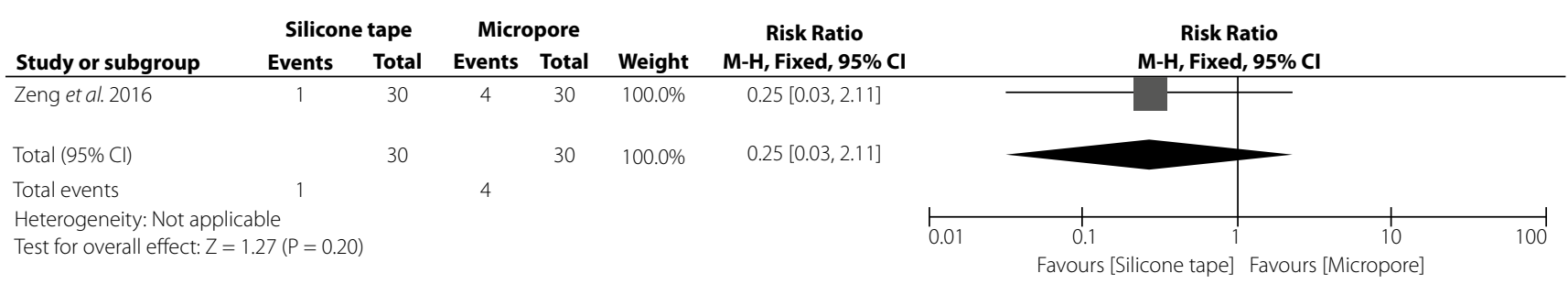

Figure 3. Incidence of moderate or severe skin injuries in patients with fragile skin.

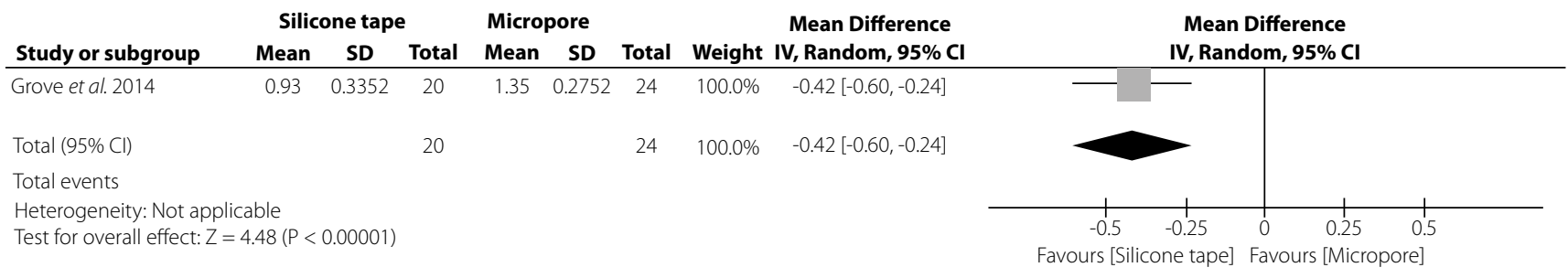

Figure 4. Erythema and edema response to a single application and removal of tapes in patients with fragile skin.

\section{Quality assessment}

In general, we found low risk of bias for random sequence generation and incomplete outcome data. Still, a high risk of bias for the masking of participants, personnel, and data assessors, and selective reporting were observed. Two of the three studies were funded by 3M (Grove et al., 2013, 2014), producer of the $3 \mathrm{M}^{\mathrm{TM}}$ Kind Removal Silicone Tape, and the other did not report sources of funding (Zeng et al., 2016) (Figure 5). The quality assessment of the evidence and the recommendation strength through GRADE indicated that the level of evidence is very low and that the recommendation is weak in favor of the technology for all assessed outcomes

\section{(Supplementary Materials - Appendix E).}

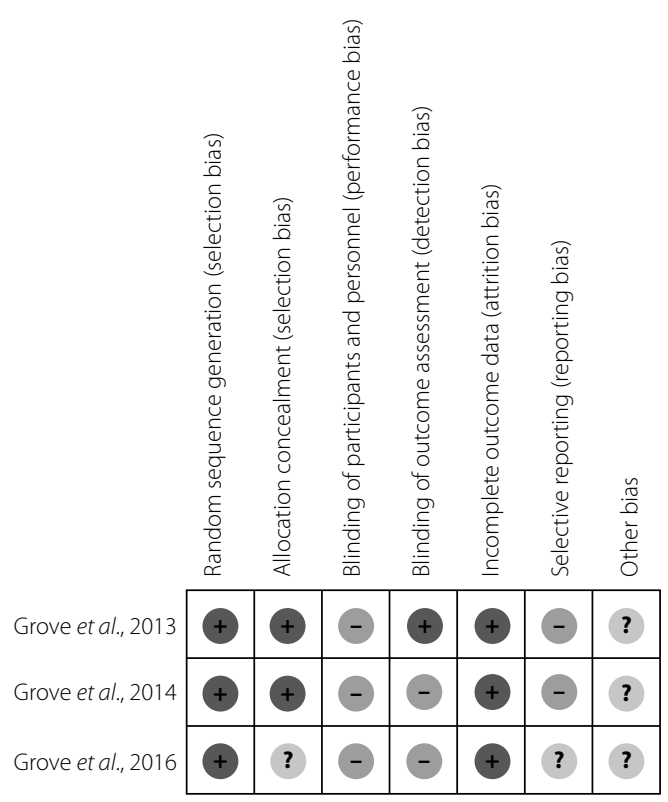

Figure 5. Risk of bias of included studies.

\section{Discussion}

This systematic review presented data that do not conclusively demonstrate the efficacy and safety advantages of silicones tapes compared to microporous tapes when used to affix materials in patients with fragile skin or high-risk of injury. Notably, there appears to be some advantage for the silicone tape in terms of safety, but this was not demonstrated with outcomes of interest such as the relative risk of injury and severe injury, infections, length of hospital stay, sepsis, or even mortality. Although the silicone tape shows significant results for some of the outcomes presented (e.g., skin-stripping, transepidermal water loss, and keratin removal from the skin), the clinical significance of the findings is uncertain.

In December 2012, a group of 23 experts was assembled to develop a consensus on the assessment, prevention, and treatment of MARSIs. This meeting was funded by $3 \mathrm{M}$. The consensus recommended the use of silicone tapes, based on evidence that silicone adhesives are associated with a lower rate of skin injuries because of their properties. Some of the presented advantages of these products were: lower surface tension and constant adhesion in time, which generate a lower risk of skin-stripping; less propensity to remove epidermal cells; less discomfort during removal; and the fact that they are repositionable. But they alert caution in attaching it to some materials (e.g., silicone, plastic), and tubes because of the risk of tape losses (McNichol et al., 2013). This consensus predates the publication of the clinical trials included in this review.

Cutting (2008) conducted a review focusing on the occurrence of injuries associated with surgical tapes and dressings and their possible impact on patients, especially the elderly and patients with skin fragility. According to the author, the removal of acrylate, hydrocolloid, polyurethane, 


\begin{tabular}{|c|c|c|c|c|c|c|c|c|c|c|c|c|}
\hline Outcome & 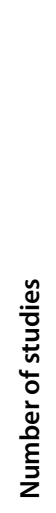 & $\begin{array}{l}\frac{n}{0} \\
\frac{0}{0} \\
\frac{0}{0} \\
\frac{y}{\underline{a}} \\
\frac{0}{x}\end{array}$ & 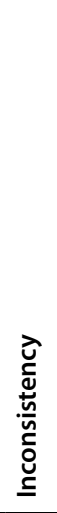 & 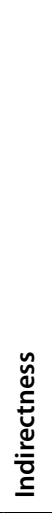 & $\begin{array}{l}\frac{\mathfrak{o}}{\mathfrak{n}} \\
\frac{\mathrm{d}}{0} \\
\underline{\underline{0}}\end{array}$ & 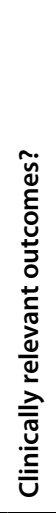 & 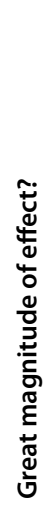 & 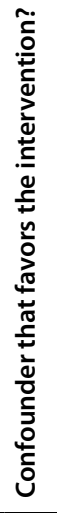 & 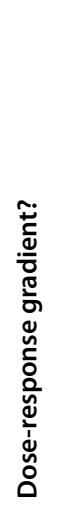 & 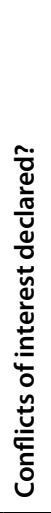 & 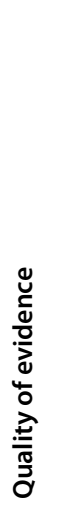 & 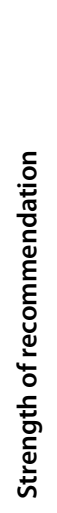 \\
\hline Incidence of injuries & 1 & - & + & - & - & + & + & + & - & + & $\begin{array}{l}\text { Very } \\
\text { Low }\end{array}$ & $\uparrow ?$ \\
\hline Incidence of moderate/severe injuries & 1 & - & + & - & - & + & + & + & - & + & $\begin{array}{l}\text { Very } \\
\text { Low }\end{array}$ & $\uparrow ?$ \\
\hline $\begin{array}{l}\text { Severity of edema/erythema after a } \\
\text { single application/removal of the tape }\end{array}$ & 2 & - & + & - & - & + & - & + & - & + & $\begin{array}{l}\text { Very } \\
\text { Low }\end{array}$ & $\uparrow ?$ \\
\hline $\begin{array}{l}\text { Severity of skin stripping after a single } \\
\text { application and removal of the tape }\end{array}$ & 2 & - & + & - & - & + & - & + & - & + & $\begin{array}{l}\text { Very } \\
\text { Low }\end{array}$ & $\uparrow ?$ \\
\hline Preference for each tape & 2 & - & + & - & - & - & - & + & - & + & $\begin{array}{l}\text { Very } \\
\text { Low }\end{array}$ & $\uparrow ?$ \\
\hline Satisfaction with each tape & 1 & - & + & - & - & - & + & + & - & + & $\begin{array}{l}\text { Very } \\
\text { Low }\end{array}$ & $\uparrow ?$ \\
\hline
\end{tabular}

and zinc oxide adhesives can cause trauma and pain, while silicone adhesives provide a safe and effective level of adhesion that, unlike acrylates, does not increase over time. The author makes a strong recommendation for silicone adhesives since, according to him, it has been shown that its removal is atraumatic and painless in curative studies in children, neonates, and adults with a variety of injuries and skin problems (Cutting, 2008). The pain and discomfort data were consistent with the findings of this review; however, this outcome is not adequate for the evaluation of the incorporation of the silicone tapes, as it has not been demonstrated that this pain and discomfort are clinically significant in any of the included studies.

There is a patients' preference for silicone tapes compared to acrylate tapes reported in one study (Zeng et al., 2016). From another perspective, Manriquez et al. (2014) evaluated the satisfaction of clinical professionals with the adhesive tapes used in their work environment. They found that 92\% ( $N=$ 196/213) of the respondents preferred to use silicone tape, and $90.2 \%$ ( $N=184 / 204)$ would be willing to change the tape they use for the silicone ones. Most respondents said they had no problem with the use of silicone tape $(75.1 \%, N=185)$. Of those who reported problems, the most commons were sliding $[\mathrm{N}=33(40.7 \%)]$ and low initial adherence $[\mathrm{N}=25$ (30.9\%)]. Some professionals reported skin irritation or injury $[\mathrm{N}=13$ (16.0\%)]. Silicone tapes were considered better or much better compared to the tapes used by the professionals on issues of skin irritation, pain on removal, initial adhesion to dry skin, good adherence to gauze and tubes, and total performance, among other aspects. This study was not comparative, randomized, or blinded and it was also funded by $3 \mathrm{M}$ (Manriquez et al., 2014).

The outcomes found in the included studies are inadequate to support decision making. They are typically intermediate outcomes with poor linkageto outcomes, suchas transepidermal water loss, skin-stripping, keratin removal, pain, user satisfaction, and professional preference. In general, the sample sizes and time horizons were small, and two of the three studies were conducted in healthy individuals. The population of infants and children showed a statistically significant difference in the occurrence of edema and erythema, unlike other populations, which is possibly associated with the greater fragility of the skin of these patients. None of the studies selected a population of preterm neonates, limiting the use of these data for this particular decision (Grove et al., 2013, 2014). The quality of the included studies was low, the level of evidence was also very low, and the strength of recommendation was weak regarding the technology. The relative risk of injury was not reported in the studies, so it had to be estimated from the study by Zeng et al. (2016), in which the skin injuries were evaluated in patients undergoing surgery under general anesthesia. Data from a single application and removal has minimal importance for assessing a scenario of real-world hospitalization. The difference 
in the populations and data presentation between trials did not allow data to be aggregated in a meta-analysis.

\section{Conclusion}

The evidence suggests that silicone tapes may be gentler to patients' skin than microporous tapes. However, the studies were not conducted with a population of interest, and the outcomes are not ideal for decision making. No data have been found to justify the argument that silicone tapes reduce infections, sepsis, or risk of death. The studies have very few participants, a short time horizon, and the quality of evidence is very low. Some consensuses recommend the use of silicone tapes to avoid injury, but $3 \mathrm{M}$ funded these. In conclusion, there is insufficient information to allow the recommendation of silicone tapes to prevent skin injuries compared to microporous tapes. Larger, longer, and methodologically better studies are necessary to demonstrate the suggested advantage.

\section{References}

Brasil. Diretrizes Metodológicas: Sistema GRADE - manual de graduação da qualidade da evidência e força da recomendação para tomada de decisão em saúde. Brasília: Ministério da Saúde; 2014.

Brasil. Lei no 10.741, de 1 de outubro de 2003. 2003. Available at: http://www. planalto.gov.br/ccivil_03/LEIS/2003/L10.741.htm.

Chang YY, Carville K, Tay AC. The prevalence of skin tears in the acute care setting in Singapore. Int Wound J. 2016;13(5);977-83. doi: 10.1111/iwj.12572

Cutting KF. Impact of adhesive surgical tape and wound dressings on the skin, with reference to skin stripping. J Wound Care. 2008;17(4):157-8, 160-2. doi: 10.12968/jowc.2008.17.4.28836

Denyer J. Reducing pain during the removal of adhesive and adherent. $\mathrm{Br} \mathrm{J}$ Nurs. 2011;20(15):S28, S30-5. doi: 10.12968/bjon.2011.20.Sup8.S28

Eichenfield LF, Hardaway CA. Neonatal dermatology. Curr Opin Pediatr.1999;11(5):471-4.

Farris MK, Petty M, Hamilton J, Walters SA, Flynn MA. Medical AdhesiveRelated Skin Injury Prevalence Among Adult Acute Care Patients : A Single-Center Observational Study. J Wound Ostomy Continence Nurs. 2015;42(6):589-98. doi: 10.1097/WON.0000000000000179

Grove GL, Zerweck CR, Ekholm BP, Smith GE, Koski NI. Randomized comparison of a silicone tape and a paper tape for gentleness in healthy children. J Wound Ostomy Continence Nurs. 2014;41(1):40-8. doi: 10.1097/01.WON.0000436669.79024.b0

Grove GL, Zerweck CR, Houser TP, Smith GE, Koski NI. A randomized and controlled comparison of gentleness of 2 medical adhesive tapes in healthy human subjects. J Wound Ostomy Continence Nurs. 2013;40(1):51-9. doi: 10.1097/WON.0b013e318276f2a4

Guyatt GH, Oxman AD, Kunz R, Falck-Ytter Y, Vist GE, Liberati A, et al.; GRADE Working Group. Going from evidence to recommendations. BMJ. 2008;336(7652):1049-51. doi: 10.1136/bmj.39493.646875.AE
Guyatt GH, Oxman AD, Kunz R, Jaeschke R, Helfand M, Liberati A, et al.; GRADE Working Group. Incorporating considerations of resources use into grading recommendations. BMJ. 2008;336(7654):1170-3. doi: 10.1136/ bmj.39504.506319.80

Guyatt GH, Oxman AD, Kunz R, Vist GE, Falck-Ytter Y, Schünemann HJ; GRADE Working Group. What is "quality of evidence" and why is it important to clinicians? BMJ. 2008;336(7651):995-8. doi: 10.1136/bmj.39490.551019.BE

Guyatt GH, Oxman AD, Vist GE, Kunz R, Falck-Ytter Y, Alonso-Coello P, et al.; GRADE Working Group. GRADE: an emerging consensus on rating quality of evidence and strength of recommendations. BMJ. 2008;336(7650):924-6. doi: 10.1136/bmj.39489.470347.AD

Higgins J, Green S. Cochrane Handbook for Systematic Reviews of Interventions Version 5.1.0. The Cochrane Collaboration. 2011. Available at: http://handbook.cochrane.org.

Konya C, Sanada H, Sugama J, Okuwa M, Kamatani Y, Nakagami G, et al. Skin injuries caused by medical adhesive tape in older people and associated factors. J Clin Nurs. 2010;19(9-10):1236-42. doi: 10.1111/j.1365-2702.2009.03168.x

Maene B. Hidden costs of medical tape-induced skin injuries. Wounds UK. 2013;9(1):46-50

Manriquez S, Loperfido B, Smith G. Evaluation of a new silicone adhesive tape among clinicians caring for patients with fragile or at-risk skin. Adv Skin Wound Care. 2014;27(4):163-70. doi: 10.1097/01. ASW.0000444646.43044.df

McNichol L, Lund C, Rosen T, Gray M. Medical adhesives and patient safety: state of the science: consensus statements for the assessment, prevention, and treatment of adhesive-related skin injuries. Orthop Nurs. 2013;32(5):267-81. doi: 10.1097/NOR.0b013e3182a39caf.

Moher D, Liberati A, Tetzlaff J, Altman DG; PRISMA Group. Preferred Reporting Items for Systematic Reviews and Meta-Analyses: The PRISMA Statement. PLoS Med. 2009;6(7):e1000097.

Noonan C, Quigley S, Curley MA. Skin integrity in hospitalized infants and children: a prevalence survey. J Pediatr Nurs. 2006;21(6):445-53. doi: 10.1016/j.pedn.2006.07.002

Ratliff CR. Descriptive study of the frequency of medical adhesive-related skin injuries in a vascular clinic. J Vasc Nurs. 2017;35(2):86-89. doi: 10.1016/j.jvn.2017.01.001

Toma TS, Pereira TV, Vanni T, Barreto JOM, orgs. Avaliação de Tecnologias de Saúde \& Políticas Informadas por Evidências. São Paulo: Instituto de Saúde; 2017.

Zeng LA, Lie SA, Chong SY. Comparison of medical adhesive tapes in patients at risk of facial skin trauma under anesthesia. Anesthesiol Res Pract. 2016;2016:4878246. doi: 10.1155/2016/4878246

Zhao $H$, He Y, Huang H, Ling Y, Zhou X, Wei Q, et al. Prevalence of medical adhesive-related skin injury at peripherally inserted central catheter insertion site in oncology patients. J Vasc Access. 2018a;19(1):23-27. doi: 10.5301/jva.5000805

Zhao H, He Y, Wei Q, Ying Y. Medical Adhesive-Related Skin Injury Prevalence at the Peripherally Inserted Central Catheter Insertion Site: A Crosssectional, Multiple-Center Study. J Wound Ostomy Continence Nurs. 2018b;45(1):22-25. doi: 10.1097/WON.0000000000000394FIGURES 